\title{
MEWUJUDKAN INDONESIA SEBAGAI NEGARA POROS MARITIM DUNIA.
}

Oleh:

\section{Arman Tjoneng}

\begin{abstract}
Indonesia, a country that has given abundant natural resources with strategic geographical position and supported by the geostrategic, geopolitical, geoekonomi and geososial culture as the largest archipelago in the world. Indonesia maritime glories of the past to make the government plans to make Indonesia as the Axis Maritime World. This has become a priority of the government Jokowi-JK.

With all the challenges, related to the implementation of the vision of Indonesia as Axis Maritime world, so many things need to be corrected and must be repaired as well as various strategic steps to be taken by the government in particular is associated mindset (mind-set) of Indonesia, reform the legal system and the enforcement of maritime sovereignty in Indonesia.

In order to realize the vision of Indonesia as a maritime axis, the active participation of all parties, especially the government and the all community are needed to restore the glory of Indonesia in the field of maritime with the slogan "JALASVEVA JAYAMAHE"
\end{abstract}

Keywords: Maritime, souverignty, law system.

\section{PENDAHULUAN}

Sebagai sebuah negara, Indonesia merupakan idaman bagi semua orang. Dikaruniakan berbagai potensi dan Sumber Daya Alam (SDA) yang melimpah yang sudah seharusnya menjadi sebuah kekuatan dan amunisi untuk mencapai tujuan negara sebagaiman yang tercantum dalam Pembukaan UUD 1945. Berdasarkan catatan terkahir, jumlah pulau di Indonesia sekitar 17.500 pulau dengan garis pantai $81.000 \mathrm{KM}$ ditambah letak posisi Indonesia diantara 2 Samudera dan Benua menjadikan Indonesia sebagai negara kepulauan terbesar di Dunia (The Largest Archipelagic in the wolrd). Wilayah perairan indonesia yang sangat luas tersebut dibentuk menjadi Sea Lines of Communication (SLoC) dan tiga Alur Laut
Kepulauan Indonesia (ALKI). SLoC berlaku untuk perairan Selat Malaka, ALKI 1 meliputi Selat Sunda, ALKI 2 meliputi Selat Lombok dan Makassar, dan ALKI 3 meliputi Selat Ombai Wetar. Kelima selat yang dibentuk menjadi SLoC dan ALKI tersebut merupakan daerah yang menjadi jalur utama pelayaran kapal-kapal dagang dan sipil dunia. ${ }^{1}$

Mencermati konstelasi geografi lndonesia sedemikian rupa, bangsa lndonesia menyadari bahwa laut merupakan media pemersatu dan sebagai media penghubung antar pulau dan bahkan penghubung antar negara negara di

1 Kementerian Koordinator Bidang Perekonomian Republik Indonesia, Masterplan for Acceleration and Expansion of Indonesia Economic Development, Jakarta: Kementerian Koordinator Bidang Perekonomian Republik Indonesia, 2011, hlm. 33. 
dunia sehigga sudah sepatutnya seluruh aspek kehidupan dan penyelenggaraan negara perlu mempertimbangkan geostrategik, geopolitik, geoekonomi serta geososial budaya sebagai negara kepulauan. Pola pikir, pola sikap dan pola tindak bangsa harus didasari oleh kesadaran ruang maritim tempat kita berada, sehingga sejatinya visi maritim menjadi tuntutan dan kebutuhan bagi bangsa lndonesia.

Kenyataan di lapangan, bangsa ini terus mengalami berbagai macam problematika setelah lebih dari 70 tahun merdeka. Cita-cita pendiri bangsa (the founding fathers) untuk mewujudkan masyarakat yang adil dan makmur sejahtera serta di ridhoi oleh Allah SWT belum terwujud. Jumlah penduduk miskin yang masih sangat tinggi serta jumlah pengangguran yang tinggi juga bukti konkret dari belum terwujudnya cita-cita luhur tersebut. Hal ini diperburuk dengan kondisi akhlak, moral dan etos kerja sebagian besar birokrasi pemerintah, elit politik, aparat penegak hukum serta masyarakat umumnya.

Konsep maritime mengerucut ke permukaan seiring dengan pernyataan Presiden Joko Widodo dalam kampanye pemilihan Presiden beberapa tahun silam. Beliau mengemukakan bahwa Indonesia sudah seharusnya menjadi poros maritime dunia dan menjadikan Indonesia sebagai negara maritime terkuat di dunia. Pernyataan ini sekilas bukan merupakan pernyataan baru karena sebenarnya konsep negara maritime ini sudah lama didengungkan oleh para pendiri negara ini bahkan melihat budaya dan tradisi masyarakat asli Indonesia dengan slogan “ nenek moyangku orang pelaut" maka konsep maritime itu sendiri sudah mengakar di Indonesia. Tercatat pada zaman kerajaan
Sriwijaya than 860 Masehi, Indonesia yang saat itu dikenal dengan nama Nusantara sangat berdaulat di bidang kelautan/kemaritiman berkat armada laut yang kuat dan perdagangan laut yang besar di Nuantara.

Tetapi, dengan pernyataan Presiden Joko Widodo tersebut, membangkitkan kembali kenangan manis Indonesia yang sangat Berjaya di sector kelautan yang realita sekarang ini justru menjadi tamu di negara sendiri. Sebagaimana yang disampaikan oleh Presiden Soekarno, dalam salah satu pidatonya, Indonesia akan menjadi bangsa yang kuat jika mempunyai kemampuan perairan atau kelautan yang kuat, poros maritim juga mempunyai tujuan yang sama. Indonesia akan dibentuk menjadi sebuah negara maritim yang menjadi pusat aktivitas kelautan dunia.

Sebagai konsekuensi dari posisi lndonesia yang sangat strategis tersebut adalah perairan lndonesia menjadi sangat penting bagi masyarakat dunia pengguna laut, hal tersebut memberi arti bahwa manakala bangsa Indonesia mampu memanfaatkan peluang dan tantangan maka akan dapat meningkatkan kesejahteraan bangsa Indonesia namun demikian perlu diwaspadai pula manakala bangsa lndonesia tidak mampu mengantisipasi dan mengelola kendala dan kerawanan yang timbul maka akan berdampak terhadap keamanan dan bahkan kedaulatan.

\section{POROS MARITIM}

Sebagaimana telah disinggung diatas bahwa perairan Indonesia pada posisi silang dunia dan sejak dulu telah digunakan sebagai jalur pelayaran dan perdaganggan internasional. Frekuensi kapal asing yang 
melintasi wilayah laut yurisdiksi nasional lndonesia juga semakin meningkat seiring bergesernya pusat kegiatan ekonomi dunia dari Atlantik ke Pasifik. Sekitar $70 \%$ angkutan barang dari Eropa, Timur Tengah dan Asia Selatan ke wilayah Pasifik dan sebaliknya melalui perairan Indonesia. Oleh karena itu secara geografis sesungguhnya Tuhan telah menganugerahkan kepada Bangsa Indonesia suatu posisi yang sangat strategis sebagai poros atau sumbu jalur pelayaran dan perdagangan dunia. Namun demikian posisi strategis tersebut meskipun telah dimanfaatkan oleh pengguna laut, tidak serta merta lndonesia dapat memperoleh manfaat sebesar-besarnya untuk kesejahteraan rakyat, apabila tidak didukung oleh kemampuan memanfaatkan peluang yang ada.

Menurut Kamus Besar Bahasa Indonesia, pengertian "Maritim" berkenaan dengan lautdan berhubungan dengan pelayaran dan perdagangan di laut. Sedangkan "Poros" berarti sumbu, pusat, ujung tombak. Sehingga dapat disimpulkan bahwa Indonesia sebagai Poros Maritim adalah Indonesia yang menjadi pusat berbagai hal yang berkenaan dengan laut.

Berdasarkan doktrin Angkatan Laut yang diterbitkan tahun 2001, kata maritim diartikan berkenaan dengan laut atau berhubungan dengan pelayaran dan perdagangan. Pengertian yang lebih luas, selain menyangkut sumber-sumber daya intern laut juga menyangkut faktor ekstern laut yaitu pelayaran, perdagangan, lingkungan pantai dan pelabuhan serta faktor strategis lainnya' Kata maritim mengandung arti integrasi/gabungan, dan menunjukkan suatu lingkungan kelautan serta bukan menunjukkan institusi. Mengalir dari uraian di atas, bangsa
Indonesia patut bersyukur karena secara geografis Tuhan telah memposisikan kepulauan Indonesia pada poros maritim dunia. $^{2}$

Untuk mewujudkan visi sebagai poros maritime dunia, Presiden Joko Widodo menetapkan lima pilar utama yang diagendakan dalam pembangunan, yaitu:

1) Membangun kembali budaya maritime Indonesia;

2) Menjaga dan mengelola sumber daya laut;

3) Memprioritaskan pengembangan infrastruktur dan konektivitas maritime;

4) Melaksanakan diplomasi maritime;

5) Membangun kekuatan pertahanan maritime. $^{3}$

\section{LANGKAH STRATEGIS PEMERINTAH} YANG HARUS DILAKUKAN UNTUK MEWUJUDKAN INDONESIA SEBAGAI POROS MARITIM

Dalam mewujudkan Indonesia sebagai Poros Maritim Dunia, maka ada bebarapa hal yang harus segera dibenahi oleh seluruh elemen terkait, yaitu:

\section{a. POLA PIKIR (MIND SET) SELURUH PIHAK TERKAIT}

Untuk mewujudkan Indonesia sebagai Poros Maritim, maka hal mendasar yang

2 Laksamana TNI \{Purn $\}$ Agus Suhartono, INDONESIA POROS MARITIM DUNIA" TOPIK BAHASAN "KEDAULATAN MARITIM INDONESIA" Presentasi dalam Seminar dan Lokakarya Kelautan Nasional, Bandung: Universitas Padjadjaran, 9-10 Juni 2015.

${ }^{3}$ Etty R. Agoes, Diplomasi Maritim dan Konvensi PBB tentang Hukum Laut (Unclos) 1982, Presentasi dalam Seminar dan Lokakarya Kelautan Nasional, Universitas Padjadjaran Bandung, 9-10 Juni 2015. 
harus dimiliki oleh segenap elemen yang ada adalah pola pikir yang seragam akan Poros Maritime Indonesia. Mewujudkan poros maritime tidaklah menjadi tugas yang ringan karena hal ini merupakan sebuah tugas yang sangat berat. Tidaklah mungkin hal ini dapat diwujudkan sepenuhnya dalam kurun waktu yang singkat dan tidak sepenuh hati. Pemerintah Jokowi-JK harus menjadikan visi ini sebagai suatu tema besar dan direalisasikan dengan sebaik-baiknya bukan hanya sekedar slogan kampanye dan pencitraan saja. Selain itu juga, harus disadari bahwa pemerintah Jokowi-JK hanya meletakkan kembali pilar-pilar dasar untuk mewujudkan kejayaan bangsa Indonesia masa lampau di bidang maritime. Oleh karena itu, visi ini harus menjadi sebuah hal yang terus dibangun dan terus dilakukan oleh pemerintah baik oleh pemerintah sekarang maupun pemerintah yang akan datang. Apabila visi ini hanya konsen dilakukan dalam pemerintahan sekarang dan tidak menjadi prioritas bagi pemerintahan yang akan datang, maka bias dipastikan visi untuk mewujudkan Indonesia sebagai Poros Maritim hanya sebuah slogan dan angin segar saja. Visi ini harus menjadi "visi Indonesia" bukan hanya menjadi visi pemerintah Jokowi-JK.

Oleh karena itu, agar menjadi Visi Indonesia, maka janganlah membebankan permasalahan ini hanya kepada satu instansi saja karena tidaklah mungkin satu instansi dapat mewujudkan visi besar ini tetapi harus ada koordinasi dan lintas sektoral yang baik. Tetapi yang harus diingat pula bahwa jangan sampai karena alasan lintas sektoral, maka terjadi tumpang tindih kewenangan yang bukannya memberikan nilai positif justru melemahkan langkah mewujudkan visi ini.

Oleh karena perwujudan visi ini harus melibatkan segenap elemen terkait, maka peran masyarakat sebagai sebuah elemen sangat diperlukan khususnya terkait dengan budaya hukum yang ada. Semakin baik budaya hukum masyarakat Indonesia dalam bidang kemaritiman, maka semakin besar pula peluang kita untuk mewujudkan visi ini. Mengingat perwujudan visi ini memerlukan waktu yang tidak singkat, maka peranan dan kepedulian generasi muda sekarang sangatlah diharapkan agar kejayaan bangsa Indonesia di masa lalu dapat dinikmati kembali oleh generasi muda. Generasi muda harus memiliki sifat sense of ownership ${ }^{4}$. Jangan sampai kekurang kepedulian bahkan kekurangpahaman masyarakat Indonesia akan kemaritiman justru menjadi sebuah problematika tersendiri bagi pemerintah dalam menegakkan hukum maritime. Bias jadi pemerintah dengan segala konsep dan programnya akan berbenturan dengan masyarakat yang tidak mengerti akan dunia maritime. Hal ini perlu penanganan serius dan sistematis dari pemerintah mengingat masyarakat pesisir yang mungkin lebih mementingkan bagaimana caranya untuk dapat bertahan hidup ketimbang memikirkan mewujudkan visi tresebut. Untuk mewujudkan kejayaan

\footnotetext{
${ }^{4}$ Hikmahanto Juwana, Mewujudkan Visi Poros Maritim dalam Perspektif Hukum, Media Indonesia, Rabu, 15 Oktober 2015.
} 
Indonesia sebagai negara maritime, maka kenyataan nasib pahit para nelayan dan masyarakat pesisir serta potret buram dunia perikanan di Indonesia harus segera diakhiri. Tentu saja bukan program ala "Robin Hood" yang sangat beraroma politis.

Sumber daya pesisir dan laut sudah selayaknya dimanfaatkan untuk sebesarbesarnya kemakmuran rakyat, bukan sekedar hak bagi para pemegang capital. Maka yang diperlukan saat ini adalah mental serta sikap yang lurus yang harus dimiliki oleh seluruh komponen di sector maritime.

Selain itu juga, yang harus diluruskan pola pikir kita adalah bahwa mewujudkan Indonesia sebagai Poros Maritim adalah visi bersama sehingga jangan sampai focus dan perhatian pemerintah hanya tertuju kepada kota-kota besar yang ada di Indonesia. Hal ini akan membuat kesenjangan antara kota-kota besar dengan kota-kota lainnya yang ada di Indonesia. Padahal kalau direnungi dengan seksama, kota-kota lainya di Indonesia akan sangat memberikan konstribusi yang baik buat mewujudkan visi ini sehingga seharusnya prioritas dan perhatian pemerintah dapat merata dan dapat terbagi dengan adil.

\section{b. PEMBENAHAN SISTEM HUKUM}

Berbicara tentang system hukum terkait mewujudkan Visi Indonesia sebagai Poros Maritim Dunia tidak saja berbicara tentang Undang-undang dan perjanjian internasional yang ada tetapi juga terkait dengan mental aparat penegak hukumnya serta budaya masyarakat yang ada sehingga segala upaya dilakukan agar semua hal tersebut dapat dimaksimalkan. Harus jujur kita akui bahwa terdapat kotradiksi terkait peraturan perundangundangan yang ada. Secara de facto masih banyak hal-hal yang belum diatur dalam peraturan perundang-undangan negara kita. Peraturan terkait maritime Indonesia masih minim jika dibandingkan dengan negara-negara maritime lainnya. Hal ini haruslah menjadi sebuah perhatian kita semua terutama para wakil rakyat. Tetapi disisi lain, walaupun masih banyak kekosongan hukum terkait kemaritiman di Indonesia, justru yang menjadi sesuatu yang harus dikritisi juga adalah tumpang tindihnya peraturan yang ada terkait kewenangan dan tugas di wilayah kemaritiman. Terjadinya benturan dan tumpang tindih peraturan perundangundangan disebabkan setiap instansi pemerintah mengedepankan kepentingan sektornya sehingga peraturan perundangundangan mencerminkan ego sektoral dari instansi. Hal ini menjadi sebuah sebuah paradok dimana ketidaklengakapan peraturan yang ada semakin memberikan efek negative dengan adanya berbagai aturan yang tumpang tindih. Akibatnya ialah masyarakat yang terkena peraturan perundang-undangan yang merasakan konsekuensinya. Situasi tersebut kerap disuarakan sebagai tidak adanya kepastian hukum. Oleh karena itu, setelah peraturan perundang-undangan yang berbenturan diidentifikasi, perlu dilakukan amendemen ataupun perubahan. Kelengkapan aturan mengenai kemaritiman dapat mencontoh kepada negara Inggris yang sangat lengkap aturan tentang kemaritiman walaupun tidak semua bias kita adopsi 
karena perbedaan geografis dan kultur yang ada tetapi minimal yang mirip dengan kondisi Indonesia bias dijadikan referensi dalam membuat aturan dimaksud. Berdasarkan data yang ada, ada \pm 30 peraturan perundang-undangan yang ada terkait pengaturan maritime di Indonesia, tetapi dari sekian banyak peraturan tersebut, sangat minim yang merujuk kepada perjanjian internasional. Seharusnya, berbagai aturan tersebut tetap mengacu kepada perjanjian internasioanl yang sudah diratifikasi agar implementasi di lapangan tidak berbenturan antara perturan perundang-undangan dan perjanjian internasional. ${ }^{5}$

Berbicara tentang penegakan hukum di wilayah maritime, pemerintahan JokowiJK telah memberikan harapan bagi masyarakat Indonesia dengan sikap tegas dalam memberantas illegal fishing dengan cara membakar dan menenggelamkan perahu-perahu negara asing yang mengambil ikan secara illegal. Walaupun pro kontra mewarnai tindakan tegas dari tindakan membakar dan menenggelamkan perahu-perahu negara asing yang mengambil ikan secara illegal, tetapi tindakan ini menunjukan bahwa Indonesia akan mempertahankan kedaulatannya dengan cara apapun dan bagaimanapun. Data statistika menunjukan bahwa terjadi pengurangan jumlah illegal fishing setelah pemberlakuan kebijakan pembakaran dan penenggelaman perahu asing ini. Tetapi tidak boleh besar kepala karena mewujudkan Indonesia sebagai Poros Maritim tidak cukup dengan hanya mengeksekusi perahu asing.

\footnotetext{
${ }^{5}$ Etty R. Agoes, op.cit.
}

\section{c. PENEGAKAN KEDAULATAN MARITIM DI INDONESIA}

Salah satu komponen yang sangat penting dalam mewujudkan Indonesia sebagai Poros Maritim Dunia adalah penegakan kedaulatan maritime di Indonesia. Hal ini menjadi sebuah keharusan dan sebuah keniscayaan mengingat luas wilayah Indonesia sebagian besar terdiri dari perairan. Ancaman dan tantangan keamanan terbesar yang ada di wilayah Asia Tenggara saat ini adalah memanasnya konflik laut China Selatan yang melibatkan beberapa negara seperti Filipina, Malaysia, Thailand, Vietnam dan lainnya. Hal ini patut diwaspadai bersama karena wilayah Laut China Selatan merupakan salah satu jalur laut tersibuk di dunia. Selain digunakan oleh sejumlah besar negara di dalam wilayah, jalur tersebut juga digunakan oleh negara di luar wilayah. Oleh karena itu, Indonesia mempunyai peranan penting dalam membangun kestabilan dan keamanan regional guna memelihara keseimbangan di antara negara-negara berkepentingan yang dikendalikan oleh kekuatan dari luar wilayah.

Untuk mengantisipasi kejadian serupa, maka hal yang harus dilakukan terkait penegakan kedaulatan mariitim adalah:

\section{1) Penentuan dan pertegasan batas zona-zona maritim Indonesia.}

Indonesia memiliki kedaulatan penuh di wilayah NKRI yang merupakan satu kesatuan wilayah daratan, perairan pedalaman, perairan kepulauan dan laut territorial beserta 
dasar laut dan tanah di bawahnya, serta ruang udara di atasnya termasuk seluruh sumber kekayaan alam yang terkandung di dalamnya. Di wilayah daratan sampai dengan batas garis air rendah (low water line) atau garis pangkal (base line), termasuk teluk dan muara sungai yang dibatasi garis pangkal \{perairan pedalaman) merupakan wilayah negara yang mempunyai kedaulatan mutlak. Sedangkan wilayah laut yang meliputi laut territorial dan perairan kepulauan merupakan wilayah negara dengan kedaulatan yang dibatasi sebagaimana diatur dalam UNCLOS L982, wilayah laut tersebut mengakomodasikan berbagai kepentingan internasional seperti lintas damai, lintas transit maupun lintas alur laut kepulauan.

Indonesia juga memiliki hak hak lain, yurisdiksi dan kewajiban sebagaimana diatur dalam peraturan perundangan dan hukum internasional di wilayah perairan yurisdiksi nasional yang terdiri atas zona tambahan, Zona Ekonomi Eksklusif dan landas kontinen seperti perikanan, pertambangan, pelestarian lingkungan laut dan penanggulangan berbagai kejahatan di laut. Oleh karena itu penegakan kedaulatan dan hukum di laut diselenggarakan sesuai ketentuan hukum laut internasional, dan dilakukan oleh otoritas yang mewakili negara pantai yang merupakan bagian dari wilayah kedaulatan negara. Sedangkan di luar wilayah perairan yurisdiksi nasional, lndonesia memiliki hak dan kewajiban untuk menjaga, melindungi kepentingan nasional di dan atau lewat laut berdasarkan peraturan perundangan dan hukum internasional.

Adanya perbedaan antara perairan pedalaman, perairan kepulauan dan laut teritorial pada dasarnya ditentukan oleh hak dan kewajiban negara kepulauan dan juga hak dan kewajiban yang dimiliki oleh negara lain di perairan tersebut yaitu hak pelayaran dan penerbangan serta pemanfaatan perairan kepulauan dan laut teritorial. Kedaulatan yang dimiliki oleh negara kepulauan dapat dilaksanakan dengan memperhatikan beberapa hak yang dapat dinikmati oleh Negara lain seperti memberikan dan mengakomodasikan hak pelayaran melalui perairan kepulauan, kewajiban untuk menghormati perjanjian yang telah ada dengan negara lain sebelum pemberlakuan konvensi hukum laut, mengakui hak perikanan tradisional dan sebagainya.

Hal ini sangatlah penting di perhatikan kerana berdasarkan pengalaman di lapangan, perseteruan dan konfilk terkait kedaulatan maritime disebabkan "tidak adanya keseriusan pemerintah dalam menegaskan wilayah NKRI khususnya di bidang maritime".

\section{2) Sistem Pendeteksian Yang Baik Dan Alut Sista Penindak Dengan Kemampuan Memadai.}

Dalam menjaga kedaulatan maritime NKRI yang begitu luas, maka sangat diperlukan alat 
pendeteksian yang akurat untuk dapat melihat pergerakan dan memantau halhal yang dapat mengancam dan mengganggu kedaulatan maritime. Tentunya alat pendeteksian tersebut harus dapat mengimbangi kemampuan dan kecanggihan dari system persenjataan negara-negara lain. Selain alat pendeteksian yang baik, maka juga haru didukung oleh alut sista dengan kemampuan yang mumpuni. Alut sista merupakan gambaran kekuatan dari angkatan bersenjata suatu negara. Semakin lengkap dan semakin baik system aluis sista suatu negara maka dapat dikatakan kekuatan negara tersebut juga baik. Sudah menjadi rahasia public bahwa system alut sista di negara kita jauh ketinggalan dibandingkan dengan negara-negara tetangga seperti Singapura dan Malaysia. Padahal bila dilihat dari SDA dan segala potensi yang ada, maka Indonesia jauh di atas negara-negara tersebut, tetapi justru negara-negara dimaksud mempunyai prioritas utama daam hal menjaga kedaulatan maritime negaranya masing-masing walaupun luas wilayah lautnya jauh di bawah Indonesia. Hal ini harus segera diperbaiki mengingat semakin hari kondisi di lapangan khususnya di sekitar perairan Selat Malaka dan Laut China Selatan semakin memanas. Indonesia harus mengantisipasi segala kemungkinan terburuk dari memanasnya kondisi yang ada.

\section{3) Koordinasi yang baik dan tersistematis.}

Dalam mewujudkan kedaulatan maritime, maka sangat diperlukan adanya koordinasi yang baik dari segala elemen yang terkait. Tumpang tindih kewenangan hingga tarik menarik kepentingan yang selama ini selalu terjadi di lapangan harus segera dikoreksi dan dibenahi mengingat hal tersebut dapat melemahkan posisi Indonesia. Peraturan perundangundangan telah banyak memberikan kewenangan kepada berbagai instansi dalam menegakan hukum di laut (multy agency single task) sehingga dapat dikatakan sebagai sebuah pemborosan. Diharapkan adanya sebuah lembaga (single agency multy task) yang dapat mengkoordinasikan segala hal terkait kedaulatan di wilayah perairan yang dapat memberikan nilai positif bagi penegakan kedaulatan maritime.

\section{KESIMPULAN}

Berdasarkan pemaparan di atas, secara teoritis, sudah sewajarnya Indonesia menjadi poros maritime dunia karena ditunjang dengan kondisi geografis dan budaya leluhur bangsa Indonesia yang sejak lama dikenal sebagai Nusantara, yaitu bangsa yang sangat ahli dalam bidang maritime. Tetapi, yang menjadi catatan kita semua bahwa banyak hal yang harus dibenahi oleh pemerintah pada khususnya dan masyarakat pada umumnya agar kejayaan Indonesia sebagai penguasa maritime bias diperoleh kembali dengan memnafaat segala potensi dan kemampuan yang ada. Sudah menjadi tugas kita semua 
untuk mengembalikan kembali kejayaan Indonesia di bidang maritime dengan slogan "JALASVEVA JAYAMAHE"

Agar cita-cita untuk mewujudkan Indonesia sebagai poros maritime dunia bias terwujud, maka sangat diperlukan peran aktif dari segala elemen bangsa yaitu :

a. Pemerintah :

Sebagai pemegang mandate dari seluruh bangsa Indonesia, Pemerintah harus segera membenahi system hukum yang ada terkait pelaksaanan poros maritime agar tidak lagi terjadi tumpang tindih aturan sehingga tidak terjadi "chaos" dalam implementasi aturan-aturan tersebut. Koordinasi antar instansi juga harus diperjelas sehingga tidak terjadi over lap kewenangan.

Pemerintah harus tegas dalam hal menjaga kedaulatan NKRI khususnta dalam wilayah maritime terhadap upaya-upaya yang tidak terpuji dari negara-negara lain yang mencoba mengklaim wilayah perairan Indonesia.

b. Masyarakat :

Harus pro aktif dalam mendukung segala program pemerintah dengan selalu melaksanakannya dengan penuh rasa tanggung jawab dan tidak justru menjadi "penghalang"

Tidaklah sulit bagi Indonesia untuk mewujudkan visi mulia sebagai Poros Maritim Dunia. Tetapi seringkali implementasi di lapangan berbeda dengan konsep dan teori yang ada sehingga sering terjadi gap antara keharusan dan kenyataan.

\section{DAFTAR PUSTAKA}

\section{Buku dan Artikel Ilmiah}

Kementerian Koordinator Bidang Perekonomian Republik Indonesia. . Masterplan for Acceleration and Expansion of Indonesia Economic Development, Kementerian Koordinator Bidang Perekonomian Republik Indonesia, Jakarta, 2011.

Laksamana TNI \{Purn\} Agus Suhartono, INDONESIA POROS MARITIM DUNIA" TOPIK BAHASAN "KEDAULATAN MARITIM INDONESIA" Presentasi dalam Seminar dan Lokakarya Kelautan Nasional, Universitas Padjadjaran Bandung, 9-10 Juni 2015.

Etty R. Agoes, Diplomasi Maritim dan Konvensi PBB tentang Hukum Laut (Unclos) 1982, Presentasi dalam Seminar dan Lokakarya Kelautan Nasional, Universitas Padjadjaran Bandung, 9-10 Juni 2015.

Hikmahanto Juwana, Mewujudkan Visi Poros Maritim dalam Perspektif Hukum, Media Indonesia, Rabu, 15 Oktober 2015.

\section{Peraturan Perundng-undangan}

The United Nations Convention on the Law of the Sea (UNCLOS)

\section{Lain-lain}

Kamus Besar Bahasa Indonesia 